\title{
Research on the Relationship between the Female Directors' Personal Characteristics and the Quality of Accounting Information
}

\author{
$L u$ Yin $^{*}$ \\ School of Economics and Management, Nanchang Hangkong University, Jiangxi, China
}

\begin{abstract}
This paper explores the relationship between female directors and the quality of accounting information. it takes 51 enterprises from 2008 to 2018 as samples, selects the proportion of female directors, age, education background and financial background to study the personal characteristics. The results show that: the percentage of female directors is directly proportional to the accounting information; the higher the female director's education, the higher the quality of information; the female directors with financial background have a specific positive effect on the improvement of accounting information. Based on this, this paper proposes some suggestions on how to strengthen the construction of the board of directors and improve the quality of information about listed companies.
\end{abstract}

Keywords: Listed companies, Female director, Quality of accounting information, Personal characteristics

\section{Introduction}

In recent years, the distortion of accounting information of listed companies emerges in endlessly. The root cause is that the accounting information quality is reduced because of the defects of corporate governance structure. As an internal governance organization, this is in a crucial core position of corporate governance. With more and more women appearing in the top management groups, people are increasingly concerned about the effectiveness of female leadership. There are obvious differences between female and male in their solutions and styles. In this context, this paper takes the female directors as sample, discusses the impact of personal characteristics of female directors on the accounting information quality.

\section{Literature review}

Carter et al. (2003) conducted an empirical study found that the more women on the board of directors, the higher the company value [1]. Ren hao (2010) explored corporate performance is better when there are women in the executive group, and it will be strengthened with the improvement of human capital and social capital of female senior managers [2]. Srinidhi et al. (2011) believe that compared with male executives, female

\footnotetext{
* Corresponding author: 48261846@qq.com
} 
executives can bring a management culture that is good at communication, mutual trust and win-win cooperation, so as to effectively reduce the opacity of company information [3]. Zhang Bin (2015) analyze the relationship between the information disclosure about listed companies and. the characteristics of female directors. The research results show that the higher the percentage of female directors, the higher the quality of accounting information. At the same time, the study of female directors has a positive impact on the quality of accounting information [4].

According to the above literature review, the participation of female directors can also urge the fulfillment of corporate social responsibility. At the same time, the quality of statements also reflects the company's sense of social responsibility. The participation of female can improve the accounting information quality, strengthen accounting conservatism, and optimize the level of accounting information disclosure. This paper draws on the research experience of past scholars and judges the quality of enterprise accounting information according to the enterprise information quality rating issued by Shenzhen Stock exchange every year.

\section{Theoretical analysis and research hypothesis}

The participation of female directors will have an influence on the accounting information quality. This paper intends to analyze the proportion, age, education background and the number of people with financial background in the board of directors, and put forward some assumptions.

(1) The influence of the proportion of female members on the quality of accounting information

Zhao Fang fang and Quan Ya wen (2017) shows that due to the empathy of women and the difference of gender roles, enterprises with more female executives are more inclined to disclose enterprise environmental information [5]. Compared with male directors, female directors pay more attention to details when dealing with the company's affairs, are more cautious in specific business decisions, and are more serious in information collection and processing, all help to improve the operation level of the board of directors. Female directors are more inclined to truthfully reflect the company's financial situation and disclose reliable information. Women have stronger empathy motivation and better cognition of social responsibility. They will pay more attention to the needs of stakeholders. This paper proposed the hypothesis

H1: The number and proportion of female have a positive impact on the accounting information quality

(2) The influence of the age of female on the accounting information quality

The risk preference and business decision-making of board members will change with age and experience. Some studies have shown that young people are more willing to experiment with new opportunities and adapt to the new environment [6]. According to Maslow's theory, the older the board members are, the more socially responsible they are. On the basis of satisfying their basic needs, they are willing to fulfill their social responsibilities to drive their higher needs to be satisfied [7]. In a word, this paper puts forward the hypothesis

$\mathrm{H} 2$ : the age of female board members has a positive impact on the quality of accounting information

(3) The influence of educational background on the quality of accounting information

According to the theory of human capital, human resource is capital, and its role is closely related to the intensity of investment. The more investment, it will bring greater returns to the enterprise in a certain period of time [8]. Education is the biggest investment. The higher the educational background of the board members, the higher the salary they deserve, the greater the investment of the enterprise, and the greater the final return. Highly educated 
managers can think about the situation from multiple directions, and make both personal and public interests in the decision-making process. They not only pay attention to the short-term interests of the organization, but also pay attention to the growth of long-term interests of the company, and do not violate laws and regulations and relevant policies. Therefore, this paper puts forward the following assumptions

H3: the educational background of female board members has a positive impact on the quality of accounting information

(4) The influence of financial background of female board members on the quality of accounting information

Board members have different cognitive abilities and different understanding levels of problems, which can feed back to the decisions of enterprises and accounting behaviors. In the process of women performing their duties, whether they have sufficient financial knowledge plays an important role in accounting quality [9]. At the same time, if the audit members in the board of directors have financial professional background, they will have greater supervision on the quality of accounting information, and have a greater right to speak, and their proposals in the decision-making process will have more reference value, so they will be valued and recognized by other board members. To sum up, this paper puts forward the hypothesis

H4: the financial background of female board members has a positive impact on the quality of accounting information

\section{Research design}

\subsection{Sample selection and data sources}

This paper randomly selects the data of 51 companies listed from 2008 to 2018 as the samples, according to the following principles: (1) excluding ST and * ST companies, because the financial operation status of these companies is abnormal and the comparability is low; (2) companies with missing or obviously abnormal data exist. After screening, this paper collected 553 groups of samples, excluding 69 groups of samples whose return on assets was blank, and 41 groups of samples whose number of female directors was 0 in the analysis of personal characteristics. Based on this, this paper collected 484 groups of effective samples for empirical study. The selection of dependent variables and control variables in this paper is mainly from CSMAR.

\subsection{Variable design}

\subsubsection{Explained variable}

The explanatory variable of this paper is the quality of information disclosure of listed companies on the main board of Shenzhen Stock Exchange. Since 2001, it finally divided the disclosure quality into four grades: excellent (a), good (b), passing (c) and failing (d). this paper uses 3, 2, 1, 0 to assign $\mathrm{A}, \mathrm{B}, \mathrm{C}$ and $\mathrm{D}$ respectively according to the evaluation results of information disclosure quality.

\subsubsection{Explanatory variables}

This paper studies the impact of female directors' personal characteristics on the accounting information quality. In this paper, the personal characteristics of female directors mainly use 
the proportion, age, education background and financial background to explore the relationship between the accounting information qualities.

\subsubsection{Control variable}

This paper quotes four control variables: asset liability ratio (Lev), return on net assets (ROA), board structure (DSIZE) and number of board shares (DSH).

Table 1. Symbol definition.

\begin{tabular}{|c|c|c|c|}
\hline $\begin{array}{l}\text { Properties } \\
\text { of variables }\end{array}$ & Variable name & Symbol & Variable definition \\
\hline $\begin{array}{l}\text { Explained } \\
\text { variable }\end{array}$ & $\begin{array}{l}\text { Quality of accounting } \\
\text { information disclosure }\end{array}$ & DISC & $\mathrm{A}$ is $3, \mathrm{~B}$ is $2, \mathrm{C}$ is $1, \mathrm{D}$ is 0 \\
\hline \multirow[t]{4}{*}{$\begin{array}{l}\text { Explanator } \\
\text { y variables }\end{array}$} & Proportion & PER & $\begin{array}{l}\text { Number of female directors in board } \\
\text { teams }\end{array}$ \\
\hline & Age & AGE & Average age of female directors \\
\hline & Education & EDU & $\begin{array}{l}\text { Average educational background of } \\
\text { female directors. Among them, } \\
\text { technical secondary school or below } \\
\text { is } 1 \text {, junior college is } 2 \text {, } \\
\text { undergraduate is } 3 \text {, master is } 4 \text {, } \\
\text { doctor and above is } 5\end{array}$ \\
\hline & Financial background & BACK & $\begin{array}{l}\text { Number of female directors with } \\
\text { financial background }\end{array}$ \\
\hline \multirow[t]{4}{*}{$\begin{array}{l}\text { Control } \\
\text { variable }\end{array}$} & Asset liability ratio & LEV & $\begin{array}{l}\text { Ratio of total liabilities to total assets } \\
\text { at the end of the year }\end{array}$ \\
\hline & ROA & $\mathrm{ROA}$ & $\begin{array}{l}\text { The ratio of the net profit of the } \\
\text { previous year to the total assets at the } \\
\text { end of the previous year }\end{array}$ \\
\hline & Board structure & DSIZE & $\begin{array}{l}\text { Proportion of independent directors } \\
\text { in the board of directors }\end{array}$ \\
\hline & Number of board shares & DSH & $\begin{array}{l}\text { Shares that held by the board of } \\
\text { directors }\end{array}$ \\
\hline
\end{tabular}

\subsection{Model building}

This paper establishes the following model according to the correlation among dependent variables, independent variables and control variables $\mathrm{DISC}=\mathrm{b}_{0}+\mathrm{b}_{1} \mathrm{PER}+\mathrm{b}_{2} \mathrm{AGE}+\mathrm{b}_{3} \mathrm{EDU}+\mathrm{b}_{4} \mathrm{BACK}+\mathrm{b}_{5} \mathrm{LEV}+\mathrm{b}_{6} \mathrm{ROA}+\mathrm{b}_{7} \mathrm{DSIZE}+\mathrm{b}_{8} \mathrm{DSH}+\mathrm{e}(1)$

\section{Figures and tables}

\subsection{Descriptive statistical analysis}

Table 2 shows the situation of the quality ratings and the personal characteristics of female directors of 51 listed companies in the past decade. 
Table 2. Descriptive statistical results.

\begin{tabular}{|l|c|c|c|c|c|}
\hline & $\mathrm{N}$ & Min & Max & Mean & Standard \\
\hline Quality rating & 484 & 0 & 3.0 & 2.041 & 0.7240 \\
\hline $\begin{array}{l}\text { Proportion of } \\
\text { women }\end{array}$ & 484 & $3.85 \%$ & $39.33 \%$ & $27.5034 \%$ & 0.1211842 \\
\hline Age & 484 & 32.33 & 64.50 & 47.0749 & 4.81164 \\
\hline Education & 484 & 1.000 & 5.000 & 3.38686 & 0.766696 \\
\hline $\begin{array}{l}\text { Financial } \\
\text { background }\end{array}$ & 484 & 0 & 8 & 2.46 & 2.183 \\
\hline $\begin{array}{l}\text { Asset liability } \\
\text { ratio }\end{array}$ & 484 & 0.0437 & 1.4110 & 0.561122 & 0.2026825 \\
\hline ROA & 484 & -0.187188 & 0.201387 & 0.069957 & 1.3759870 \\
\hline $\begin{array}{l}\text { Proportion of } \\
\text { independent } \\
\text { directors }\end{array}$ & 484 & 0.29 & 1.00 & 0.3644 & 0.05516 \\
\hline $\begin{array}{l}\text { Number of } \\
\text { shares held } \\
\text { by the board } \\
\text { of directors }\end{array}$ & 484 & 0 & 584674581 & 9465576.94 & 53347630.370 \\
\hline Effective $\mathrm{n}$ & 484 & & & & \\
\hline
\end{tabular}

From the random sampling, the largest percentage of female directors is $39.33 \%$, the minimum is $3.85 \%$, and the average percentage of women is more than $25 \%$. This shows that in recent ten years, China's enterprise board of directors has gradually paid attention to gender heterogeneity, but compared with the number of men, the proportion is still relatively low, and the number of different enterprises is different. From the perspective of age and educational background, the average age of female directors is 47.07 years old, which is younger. Among them, the oldest company is 64.5 years old, and the youngest is 32.33 years old. From the educational background of female directors, the average educational background is undergraduate and graduate students, which is higher on the whole. According to the number of female directors with financial background, there are 2.46 female with financial background in each company. In addition, from the perspective of asset liability ratio, the average is $56.11 \%$, but the range is from $4.37 \%$ to $141.1 \%$, which shows that the gap of asset liability ratio of listed companies is very large. From the perspective of ROA, the average value is $6.99 \%$, but the range is from $-18.71 \%$ to $20.13 \%$, which shows that the difference of ROA is large. From the perspective of the proportion of independent directors, the average number is $36.44 \%$, the range is from $29 \%$ to $100 \%$, which shows that the proportion of independent directors of listed companies is not big. From the perspective of the number of shares held by the board of directors, the average number is 9465576.94 , the minimum value is 0 , but the maximum value is more than 500 million, which shows that the level of the number of shares held by the board of directors of domestic listed companies changes greatly. 


\subsection{Correlation analysis}

Table 3. Multiple regression coefficient results.

\begin{tabular}{|l|l|l|l|l|l|l|l|}
\hline & & $\begin{array}{l}\text { Quality } \\
\text { Grade }\end{array}$ & $\begin{array}{l}\text { Female } \\
\text { Number }\end{array}$ & $\begin{array}{l}\text { Female } \\
\text { Proportion }\end{array}$ & Age & Education & $\begin{array}{l}\text { Finance } \\
\text { Background }\end{array}$ \\
\hline $\begin{array}{l}\text { Quality } \\
\text { rating }\end{array}$ & Relevance & 1.000 & $0.726^{* *}$ & $0.638^{* *}$ & $0.110^{*}$ & $0.703^{* *}$ & $0.635^{* *}$ \\
\hline $\begin{array}{l}\text { Proportion } \\
\text { of women }\end{array}$ & Relevance & $0.638^{* *}$ & $0.741^{* *}$ & 1.000 & $0.111^{* *}$ & $0.441^{* *}$ & $0.380^{* *}$ \\
\hline Age & Relevance & $0.110^{*}$ & 0.185 & 0.111 & 1.000 & 0.019 & 0.025 \\
\hline Education & Relevance & $0.703^{* *}$ & $0.518^{* *}$ & $0.441^{* *}$ & 0.019 & 1.000 & $0.554^{* *}$ \\
\hline $\begin{array}{l}\text { Financial } \\
\text { background }\end{array}$ & Relevance & $0.635^{* *}$ & $0.609^{* *}$ & $0.380^{* *}$ & 0.025 & $0.554^{* *}$ & 1.000 \\
\hline
\end{tabular}

"** significant correlation at 0.01 level (bilateral); * significant correlation at 0.05 level (bilateral).

From the results in the table 3 , we can see that some variables in the table have correlation, but the correlation coefficient is not large, so there is no need to worry about multicollinearity between independent variables. The table shows that the proportion of women in the board of directors and the number of female directors with financial background are significantly positively correlated with the company's information quality rating at the level of 0.01 , which is consistent with the hypothesis. At the level of 0.01 , there is a significant positive correlation between female directors' education and quality rating, which is consistent with the hypothesis. The preliminary results show that gender differentiation of board of directors; high education and financial background of female directors are conducive to the improvement of accounting information quality. However, the average age of female directors is not significantly correlated with the quality rating at the level of 0.05 , which is inconsistent with the hypothesis. 


\subsection{Multiple regression analysis}

Table 4. Multiple regression coefficient.

\begin{tabular}{|c|c|c|c|c|c|c|}
\hline \multicolumn{2}{|l|}{ Model } & \multicolumn{2}{|c|}{$\begin{array}{l}\text { Coefficient of non } \\
\text { standardization }\end{array}$} & \multirow{2}{*}{\begin{tabular}{|c}
$\begin{array}{l}\text { Standardizatio } \\
\text { n coefficient }\end{array}$ \\
Beta
\end{tabular}} & \multirow[t]{2}{*}{$\mathrm{T}$} & \multirow[t]{2}{*}{ Sig. } \\
\hline & & B & Standard error & & & \\
\hline \multirow[t]{5}{*}{1} & (Constant) & -0.315 & 0.198 & & -1.590 & 0.113 \\
\hline & Proportion of women & 0.012 & 0.002 & 0.207 & 5.658 & 0.000 \\
\hline & Age & 0.005 & 0.004 & 0.031 & 1.224 & 0.222 \\
\hline & Education & 0.349 & 0.030 & 0.369 & 11.685 & 0.000 \\
\hline & Financial background & 0.064 & 0.011 & 0.194 & 5.631 & 0.000 \\
\hline $\begin{array}{l}\text { a. dependent } \\
\text { variable }\end{array}$ & : Quality rating & & & & & \\
\hline
\end{tabular}

This paper adopts the method of multiple linear regression analysis. The regression coefficient is shown in Table 4. From the data in the table, it can be seen that the proportion of women is significantly positively correlated with the quality rating at the level of 0.01 , and the non-standard coefficient is 0.012 , which indicates that increasing the percentage of women in the board of directors has a positive effect on the improvement of quality rating. The average age and quality rating of female directors is greater than 0.05 , which indicates that there is no correlation between them. The age of female directors has little relationship with the accounting information quality. At the level of 0.01 , there is a significant positive correlation between the average educational background of female directors and the quality rating, and the non-standard coefficient is 0.349 , which indicates that the higher the educational background of female directors, the stronger the sense of social responsibility, and the higher the quality of information disclosure. The number of female directors with financial background is significantly positively correlated with the quality rating at the level of 0.01 , and the non-standard coefficient is 0.064 , which indicates that the recruitment of female directors with financial background to participate in major decisions is conducive to improving the quality of information disclosure.

\subsection{Robustness test}

In order to further verify the reliability of the above regression results, starting from the data, this paper adjusts the classification according to different standards, divides the proportion of female directors, age, education background and the number of people with financial background into three levels, and replaces them with "0", "1" and "2", and carries out correlation analysis and regression analysis. The test results are shown in Table 5 and table 6. 
Table 5. Results of correlation analysis.

\begin{tabular}{|c|c|c|c|c|c|c|c|}
\hline & & $\begin{array}{l}\text { Quality } \\
\text { Grade }\end{array}$ & $\begin{array}{l}\text { Female } \\
\text { Number }\end{array}$ & $\begin{array}{l}\text { Female } \\
\text { Proportion }\end{array}$ & Age & $\begin{array}{l}\text { Educat } \\
\text {-ion }\end{array}$ & $\begin{array}{l}\text { Finance } \\
\text { Background }\end{array}$ \\
\hline $\begin{array}{l}\text { Quality } \\
\text { rating }\end{array}$ & Relevance & 1.000 & $0.608 * *$ & $0.556^{* *}$ & $0.060^{*}$ & $\begin{array}{l}0.550^{*} \\
*\end{array}$ & $0.639 * *$ \\
\hline $\begin{array}{l}\text { Proportion } \\
\text { of women }\end{array}$ & Relevance & $0.556^{* *}$ & $0.654 * *$ & 1.000 & $0.120 * *$ & $\begin{array}{l}0.334 * \\
*\end{array}$ & $0.408 * *$ \\
\hline Age & Relevance & $0.060^{*}$ & 0.179 & 0.120 & 1.000 & 0.022 & 0.063 \\
\hline Education & Relevance & $0.550 * *$ & $0.261 * *$ & $0.334 * *$ & 0.022 & 1.000 & $0.406^{* *}$ \\
\hline $\begin{array}{l}\text { Financial } \\
\text { background }\end{array}$ & Relevance & $0.639 * *$ & $0.488 * *$ & $0.408 * *$ & 0.063 & $\begin{array}{l}0.406^{*} \\
*\end{array}$ & 1.000 \\
\hline
\end{tabular}

"** significant correlation at 0.01 level (bilateral); * significant correlation at 0.05 level (bilateral).

Table 6. Multiple regression coefficient results.

\begin{tabular}{|c|c|c|c|c|c|c|}
\hline \multirow[t]{2}{*}{ Model } & & \multicolumn{2}{|c|}{$\begin{array}{l}\text { Coefficient of non } \\
\text { standardization }\end{array}$} & \multirow{2}{*}{\begin{tabular}{|c|}
$\begin{array}{l}\text { Standardization } \\
\text { coefficient }\end{array}$ \\
Beta
\end{tabular}} & \multirow[t]{2}{*}{$\mathrm{T}$} & \multirow[t]{2}{*}{ Sig. } \\
\hline & & B & Standard error & & & \\
\hline \multirow[t]{5}{*}{1} & (constant) & 0.999 & 0.074 & & 13.553 & 0.000 \\
\hline & $\begin{array}{l}\text { Proportion of } \\
\text { women }\end{array}$ & 12.338 & 3.218 & 0.142 & 3.834 & 0.000 \\
\hline & Age & -0.047 & 0.040 & -0.034 & -1.185 & 0.236 \\
\hline & Education & 0.528 & 0.056 & 0.298 & 9.450 & 0.000 \\
\hline & $\begin{array}{l}\text { Financial } \\
\text { background }\end{array}$ & 0.410 & 0.043 & 0.326 & 9.436 & 0.000 \\
\hline
\end{tabular}

From the above table, we can see that the empirical results are basically consistent with the regression results of the original model in the significance level and the direction of correlation coefficient, which proves that the empirical results are robust. Therefore, the results of the robustness test further show that improving the gender heterogeneity of the board of directors and the education and financial knowledge level of female directors have a significant impact on the improvement of the quality of corporate statements.

\section{Conclusions and suggestions}

(1) According to statistics, the number of enterprises with female directors increased year by year. However, compared with western countries, the proportion of female members in the board of directors in China is still relatively low. And it shows that most female directors are middle-aged women. Most enterprises employ female members with higher education background as directors, which shows that the society pays more and more attention to the knowledge level of managers. From the number of female directors with financial 
background, most of them have certain financial background, so as to increase their professional level.

(2) The employment of female members by the board of directors has a positive effect on improving the level of accounting information. it shows that the percentage of female directors is positively correlated with the accounting information quality. This shows that gender differences in board members can play a positive role in guiding the management decision-making, thus improving the quality of enterprise information disclosure.

(3) Female directors with high education level have positive effect on accounting information quality. Higher education can enhance the managers' sense of social responsibility. When disclosing accounting information, they can consider the problems from a long-term perspective. Therefore enterprises should recruit more female board members with higher education, and women should also strive to improve their education and professional knowledge and skills.

(4) Female directors with financial background can improve the quality of accounting information. If female directors have studied in economics and management or have financial experience, they will have a significant positive impact on the quality of enterprise accounting information. In the process of decision-making, if female directors have relevant financial knowledge, they will pay more attention to the issues related to finance, have more voice in business decision-making of accounting information, and their opinions are more representative and professional, which has a positive impact on the quality of accounting information of listed companies.

\section{References}

1. C Souza. The Gender and Ethnic Diversity of US Boards and Board Committees and Firm Financial Performance,Corporate Governance: An International Review,18 (5),60-67,(2010)

2. H Ren. The impact of female participation in top management team on Firm Performance. Nankai management review, 13, (5),81-91, (2010)

3. F. Gul, B. Srinidhi. Does Board Gender Diversity Improve the Informative of Stock Prices. Journal of Accounting and Economics,51, (7), 314-338 (2011)

4. B Zhang. Characteristics of female directors and accounting information quality. Friends of accounting.23, (10),84-86, (2015)

5. F F Zhao. Research on the impact of executives' personal characteristics on corporate environmental information disclosure. Accounting news. 27, (11),100-104, (2017)

6. Y Q Wu. The impact of executives' personal characteristics on the quality of accounting information disclosure: An Empirical Study Based on Listed Companies in information technology industry. Friends of accounting. 30, (11),63-67, (2018)

7. G L li. Empirical Study on the relationship between corporate governance and accounting information quality. Accounting research. 12, (2),28-36, (2003)

8. Y Jia. An Empirical Study on the internal and external governance effect of accounting information quality -- Taking Shenzhen A-share listed companies as an example. Accounting and auditing. 24, (1),138-141, (2017)

9. H B Pan. Vertical concurrent management, property right and accounting information quality. Accounting research. 14, (7), 19-26, (2016) 